\title{
Evaluasi pemberian ekstrak daun kayu manis Cinnamomum burmannii pada pakan terhadap kandungan lemak daging ikan patin Pangasianodon hypopthalmus
}

\section{Evaluation of cinnamon Cinnamomun burmannii extract supplementation in diet on flesh fat content of catfish Pangasianodon hypopthalmus}

\author{
Mia Setiawati*, Dedi Jusadi, Febrina Rolin, Apriana Vinasyiam \\ Departemen Budidaya Perairan, Fakultas Perikanan dan Ilmu Kelautan, Institut Pertanian Bogor \\ Kampus IPB Dramaga Bogor, Jawa Barat 16680 \\ *Surel: aktani@indo.net.id
}

\begin{abstract}
This study aimed to evaluate the effects of cinnamon Cinnamomum burmannii leaves extract addition with different doses in diet for the lipid muscle content of catfish Pangsianodon hypophthalmus. The cinnamon leaves extract was mixed in to the diet with five doses i.e: 0 (control); $0.5 ; 1 ; 2$; and $4 \mathrm{~g} / \mathrm{kg}$ diet. Catfish $(7.43 \pm 0.01 \mathrm{~g}$ ) were reared in 15 aquariums ( $160 \mathrm{~L}$ volume) with density of 30 fishes in each aquarium for 60 days. Fish were fed until apparent satiation three times daily at $08.00,12.00,16.00 \mathrm{WIB}$. The addition of cinnamon leaves extract at $1 \mathrm{~g} / \mathrm{kg}$ of diet showed the optimal dose because it could lower flesh fat content, cholesterol, and triglycerides of catfish.
\end{abstract}

Keywords: Pangasianodon hypopthalmus, Cinnamomum burmannii, fat, flesh

\begin{abstract}
ABSTRAK
Penelitian ini bertujuan untuk mengevaluasi pengaruh penambahan ekstrak daun kayu manis Cinnamomum burmannii dengan dosis berbeda pada pakan terhadap kandungan lemak daging ikan patin Pangsianodon hypopthalmus. Ekstrak daun kayu manis dicampurkan ke dalam pakan dengan lima dosis yaitu: 0 (kontrol); 0,5; $1 ; 2 ;$ dan $4 \mathrm{~g} / \mathrm{kg}$ pakan. Ikan patin $(7,43 \pm 0,01 \mathrm{~g}$ ) dipelihara dalam 15 akuarium (volume $160 \mathrm{~L}$ ) dengan kepadatan 30 ekor/akurium selama 60 hari. Ikan diberi pakan secara at satiation sebanyak tiga kali sehari pada pukul 08.00, 12.00, dan 16.00 WIB. Hasil penelitian menunjukkan bahwa penambahan ekstrak daun kayu manis sebanyak 1 $\mathrm{g} / \mathrm{kg}$ pakan memberikan hasil yang optimal karena dapat menurunkan kandungan lemak daging, kolesterol, dan trigliserida ikan patin.
\end{abstract}

Kata kunci: Pangasianodon hypopthalmus, Cinnamomum burmannii, lemak, daging

\section{PENDAHULUAN}

Umumnya ikan patin saat ini dipasarkan tidak hanya dalam bentuk hidup, melainkan dalam bentuk filet beku dan segar. Filet patin hasil budidaya di Indonesia seringkali kalah bersaing dengan filet patin Vietnam dan tidak laku di pasaran Internasional karena tekstur daging patin Indonesia kurang kompak/lembek serta berwarna kekuningan (Suryaningrum et al., 2010). Sementara filet patin Vietnam memiliki warna daging putih atau merah muda pucat dengan kandungan lemak yang rendah (Orban et al., 2008). Menurut Suwarsito (2007) warna kekuningan daging ikan patin disebabkan antara lain oleh kandungan lemak yang tinggi. zat aditif yang saat ini banyak dikembangkan dan berpotensi untuk meningkatkan kualitas daging ikan yaitu zat aditif yang berasal dari tanaman seperti penggunaan daun kayu manis Cinnamomum burmannii pada pakan.

Daun kayu manis mengandung beberapa jenis zat aktif seperti tannin, eugenol, safrole, kalsium oksalat, damar, saponin, zat penyamak, dan sinnamaldehid (Sulistiyani et al., 2006). Menurut penelitian Wang et al. (2009) senyawa polifenol yang dominan pada daun kayu manis C. burmannii adalah dari golongan aldehid yaitu 
trans-sinnamaldehid sebesar 60,17\%. Komponen bioaktif dari golongan polifenol ini memiliki aktivitas seperti insulin (insulin mimetic) yang disebut zat methylhydroxychalcone polymer (MHCP) (Vanschoonbeek et al., 2006). Menurut Polakof et al. (2010) insulin juga berperan penting dalam proses metabolisme lipid pada jaringan adiposa di hati dan otot (daging) pada ikan rainbow trout dan telah diuji pula oleh Chao et al. (2010) dan Yamazaki et al. (2011) pada tikus, serta Preuss et al. (2006) pada kelinci. Pada kelinci, kayu manis juga berpotensi sebagai anti-hiperkolesterolemia (Azima, 2004). Hasil penelitian Azima tersebut menunjukkan penurunan total kolesterol sebesar $68,6 \%$, LDL kolesterol sebesar 66,6\%, dan kandungan trigliserida sebesar $49,9 \%$, serta peningkatkan HDL kolesterol sebesar 54,3\%.

Beberapa penelitian dengan menggunakan tepung daun kayu manis telah dilakukan pada ikan patin (Setiawati et al., 2014; Setiawati et al., 2015). Pada ikan patin berukuran 8,5 g, penambahan tepung daun kayu manis pada pakan dapat meningkatkan protein tubuh, retensi protein, dan kecernaan protein (Setiawati et al., 2014). Namun Setiawati et al. (2014) tidak mengamati kandungan lemak daging ikan patin akibat pemberian tepung daun kayu manis tersebut. Sementara hasil penelitian Setiawati et al. (2015) pada ikan patin berukuran $+20 \mathrm{~g}$ menunjukkan penambahan tepung daun kayu manis pada pakan hingga dosis 1,5\% dapat menurunkan kandungan lemak daging ikan namun tidak signifikan, penurunannya hanya sebesar $28,35 \%$ bobot kering dengan laju pertumbuhan ikan yang mengalami penurunan sebesar 52,28\%.

Diduga dengan pemberian ekstrak daun kayu manis maka dosis yang digunakan lebih tepat karena bahan-bahan aktif yang terdapat di dalam daun kayu manis dapat dimanfaatkan dengan maksimal biladibandingkan dengan menggunakan tepung daun kayu manis. Komponen-komponen kimia dalam tanaman kayu manis dapat bervariasi disebabkan oleh lokasi dan perbedaan waktu panen (umur panen). Kandungan dari komponen kimia kayu manis akan semakin meningkat dengan meningkatnya umur pohon kayu manis, meskipun kandungan komponen kimia tersebut belum atau tidak merubah kategori kandungan kimianya (Hamidah et al., 2009). Kulit kayu manis yang berumur lebih dari 9 tahun memiliki kadar sinnamaldehid sebesar 91,82\% lebih tinggi 19,45\% dibandingkan kadar sinnamaldehid kulit kayu manis berumur 3-6 tahun (Azima, 2004).
Berdasarkan hal tersebut maka perlu dilakukan evaluasi lebih lanjut mengenai pemanfaatan ekstrak daun kayu manis terhadap kandungan lemak daging ikan patin.

\section{BAHAN DAN METODE}

\section{Ekstraksi daun kayu manis}

Daun kayu manis diperoleh dari Kebun Percobaan Balai Penelitian Tanaman Obat dan Aromatika (BALITTRO) Cimanggu, Bogor. Daun kayu manis dari spesies C. burmannii dibersihkan dari kotoran yang melekat dengan air mengalir. Kemudian daun dikeringudarakan dan dihindari dari sinar matahari secara langsung. Setelah kering daun kayu manis dihaluskan dengan menggunakan mesin hingga menjadi tepung. Tepung daun kayu manis $C$. burmannii diekstraksi menggunakan etanol 96\%. Prosedur ekstraksi yang dilakukan mengikuti prosedur yang dilakukan oleh Prasad et al. (2009) dengan sedikit modifikasi. Simplisia daun kayu manis diekstraksi dengan perbandingann 1:10 antara sampel dan pelarut. Ekstraksi dilakukan menggunakan metode maserasi selama 18 jam sambil diaduk menggunakan shaker. Filrat yang didapat difiltrasi kemudian diuapkan dengan evaporator pada suhu $40{ }^{\circ} \mathrm{C}$ sehingga diperoleh ekstrak kasar daun kayu manis.

\section{Analisis proksimat dan kandungan bahan aktif daun kayu manis}

Setelah proses ekstraksi daun kayu manis selesai maka dilakukan analisis proksimat daun kayu manis serta pengujian kandungan bahan aktif yang terdapat pada ekstrak daun kayu manis. Analisis proksimat mengikuti metode yang dilakukan oleh AOAC (2012). Analisis proksimat daun kayu manis terdiri atas analisis kadar air, kadar abu, kadar protein, kadar lemak, dan karbohidrat yang terdiri atas BETN dan serat kasar. Berdasarkan hasil analisis proksimat didapatkan hasil kandungan kadar air sebesar $6,55 \%$, kadar abu sebesar 3,36\%, kadar protein sebesar 15,44\%, kadar lemak sebesar 5,21\%, BETN sebesar 40,30\%, dan serat kasar sebesar 29,14\%. Ekstrak daun kayu manis mengandung tannin sebesar $9,11 \%$, flavonoid sebesar 9,14\%, dan sinnamaldehid sebesar 5,86\%.

\section{Pakan uji}

Pakan uji yang digunakan pada penelitian ini adalah pakan buatan berupa pelet komersial untuk ikan lele dengan kandungan protein $31 \%$ yang 
dicampur ekstrak daun kayu manis dengan dosis berbeda. Setiap perlakuan terdiri atas tiga ulangan. Ekstrak daun kayu manis yang dicampurkan yaitu 0 (kontrol); 0,5; 1; 2; dan 4 g/kg pakan. Ekstrak daun kayu manis dicampurkan ke dalam pakan secara repelleting. Pakan komersial ditepungkan terlebih dahulu, kemudian ekstrak daun kayu manis dicampurkan ke dalam pakan. Pakan yang telah dicampur ekstrak daun kayu manis kemudian dicetak menjadi pelet kembali dan dikeringkan dalam oven bersuhu $30{ }^{\circ} \mathrm{C}$ selama 24 jam (Rattanachaikunsopon \& Phumkhachorn, 2010). Pakan uji yang telah selesai dibuat, dianalisis proksimat untuk mengetahui kadar nutrisi yang terkandung di dalamnya. Hasil proksimat pakan uji dalam bobot kering tercantum dalam Tabel 1 .

\section{Pemeliharaan ikan}

Ikan uji yang digunakan adalah benih ikan patin Pangasianodon hypopthalmus berukuran 3 inci yang berasal dari pembudidaya di daerah Parung, Bogor. Benih yang digunakan sebanyak 450 ekor dengan berat 7,43 $\pm 0,01 \mathrm{~g}$. Ikan uji diaklimatisasi terlebih dahulu sebelum diberi perlakuan pada satu bak tandon bervolume 1 ton selama tujuh hari. Pemeliharaan ikan menggunakan akuarium berukuran $100 \times 40 \times 50 \mathrm{~cm}^{3}$ dengan volume $160 \mathrm{~L}$ sebanyak 15 akuarium. Padat penebaran ikan 30 ekor/akuarium. Pemeliharaan dilakukan selama 60 hari dan pakan diberikan secara sampai ikan terlihat kenyang tiga kali sehari pada pukul 08.00, 12.00, dan 16.00 WIB. Jumlah pakan yang dihabiskan dicatat untuk mengetahui tingkat konsumsi pakan.

Selama pemeliharaan dilakukan pengelolaan kualitas air dengan cara melakukan pergantian air sebanyak $30 \%$ setiap tiga hari sekali agar kualitas air tetap terjaga. Pemeliharaan dilakukan menggunakan sistem resirkulasi top filter. Selama pemeliharaan kondisi kualitas air yaitu suhu berkisar $26-29{ }^{\circ} \mathrm{C}$, DO berkisar 5,2-8,0 mg/L, TAN berkisar 0,09-0,84 mg/L; dan $\mathrm{pH}$ berkisar 4,50-7,76. Pada awal dan akhir pemeliharaan dilakukan analisis proksimat tubuh dan daging ikan uji. Beberapa ekor ikan dari setiap perlakuan diambil darahnya untuk uji biokimiawi darah.

Analisis proksimat yang dilakukan meliputi analisis proksimat pakan uji, tubuh, daging, dan hati ikan awal dan akhir penelitian. Analisis pakan uji dan tubuh ikan terdiri atas pengukuran kadar air dengan pemanasan dalam oven (105$110{ }^{\circ} \mathrm{C}$ ), protein dengan metode Kjehdal, lemak dengan metode Soxhlet untuk pakan dan Folch untuk tubuh ikan, kadar abu dengan pemanasan dalam tanur $\left(400-600{ }^{\circ} \mathrm{C}\right)$ dan serat kasar diukur dengan pelarutan dalam asam dan basa kuat serta pemanasan. Sementara analisis proksimat daging dan hati ikan uji terdiri atas pengukuran kadar air dan lemak. Analisis proksimat ini dilakukan dengan metode AOAC (2012). Parameter yang diamati pada penelitian ini adalah pengamatan organ hati dan daging (otot) (kandungan air, lemak, dan indeks hepatosomatik), total kolesterol, trigliserida, dan HDL-kolesterol.

\section{Analisis data}

Penelitian ini menggunakan rancangan acak lengkap dengan lima perlakuan dan tiga ulangan. Semua parameter penelitian diuji secara statistik. Data yang diperoleh ditabulasi dan dianalisis ANOVA menggunakan program SPSS. Perlakuan yang berbeda nyata akan diuji lanjut dengan uji lanjut Duncan.

Tabel 1. Hasil proksimat pakan uji (\% bobot kering)

\begin{tabular}{lccccc}
\hline \multirow{2}{*}{ Komposisi nutrisi $(\%)$} & \multicolumn{5}{c}{ Perlakuan ekstrak daun kayu manis $(\mathrm{g} / \mathrm{kg})$} \\
\cline { 2 - 5 } & 0 & 0,5 & 1 & 2 & 4 \\
\hline Protein & 30,98 & 31,05 & 31,46 & 30,74 & 30,61 \\
Lemak & 7,83 & 7,91 & 7,86 & 7,90 & 7,79 \\
Abu & 9,47 & 8,67 & 8,45 & 8,66 & 8,60 \\
Serat kasar & 4,76 & 5,45 & 4,68 & 5,18 & 5,57 \\
BETN & 46,97 & 46,92 & 47,57 & 47,51 & 47,43 \\
GE (kkal/kg) & 444,33 & 445,31 & 449,78 & 446,00 & 443,83 \\
\hline
\end{tabular}

Keterangan:

BETN = bahan ekstrak tanpa nitrogen

$\mathrm{GE} \quad=$ gross energy (Watanabe, 1988), $1 \mathrm{~g}$ protein $=5,6 \mathrm{kkal} \mathrm{GE,} 1 \mathrm{~g}$ lemak = 9,4 kkal GE, $1 \mathrm{~g}$ karbohidrat $/$ $\mathrm{BETN}=4,2$ kkal GE 


\section{HASIL DAN PEMBAHASAN}

\section{Hasil}

Analisis proksimat daging (otot) dan hati ikan patin selama pemeliharaan 60 hari disajikan pada Tabel 2. Hasil analisis menunjukkan bahwa kadar lemak daging (otot) dan hati ikan patin semakin menurun seiring dengan peningkatan dosis ekstrak daun kayu manis pada pakan dan nilai terendah terdapat pada perlakuan penambahan dosis ekstrak daun kayu manis $4 \mathrm{~g} / \mathrm{kg}$ pakan. Indeks hepatosomatik ikan yang diberi perlakuan dosis ekstrak daun kayu manis $0,5-4 \mathrm{~g} / \mathrm{kg}$ pakan lebih rendah dibandingkan kontrol.

Analisis total kolesterol, trigliserida, dan HDL-kolesterol plasma darah ikan patin disajikan pada Tabel 3. Kadar total kolesterol dan trigliserida ikan patin menurun hingga penambahan ekstrak daun kayu manis sebanyak $1 \mathrm{~g} / \mathrm{kg}$ pakan namun kembali meningkat pada penambahan ekstrak daun kayu manis sebanyak $2 \mathrm{~g} / \mathrm{kg}$ pakan. Sementara untuk kadar HDLkolesterol pada darah sama antar perlakuan akibat dari penambahan ekstrak daun kayu manis ke dalam pakan.

\section{Pembahasan}

Kadar lemak daging (otot) ikan patin semakin menurun seiring dengan peningkatan dosis ekstrak daun kayu manis pada pakan. Nilai terendah secara berurutan terdapat pada perlakuan penambahan dosis ekstrak $0,5 \mathrm{~g} / \mathrm{kg}$ pakan sebesar

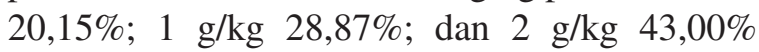
bobot kering (Tabel 3). Penurunan kadar lemak daging (otot) ini mencapai 58,65\% bobot kering pada dosis ekstrak daun kayu manis $4 \mathrm{~g} / \mathrm{kg}$ pakan dibandingkan perlakuan tanpa penambahan ekstrak daun kayu manis ke dalam pakan dan lebih besar dibandingkan dengan penurunan lemak daging (otot) ikan patin pada penelitian Setiawati et al. (2015) yang menggunakan tepung daun kayu manis. Penurunan lemak daging (otot) pada penelitian Setiawati et al. (2015) sebesar $28,35 \%$ bobot kering pada dosis tepung daun kayu manis $1,5 \%$ dengan laju pertumbuhan yang mengalami penurunan sebesar $52,28 \%$ bila dibandingkan kontrol. Hal ini menunjukkan bahwa penggunaan ekstrak daun kayu manis lebih efektif dalam menurunkan lemak daging (otot) dibandingkan penggunaan tepung daun kayu manis. Bahan-bahan aktif yang terdapat di dalam

Tabel 2. Hasil analisis proksimat daging (otot) dan hati ikan patin selama pemeliharaan 60 hari

\begin{tabular}{lccccc}
\hline \multirow{2}{*}{ Parameter uji } & \multicolumn{5}{c}{ Perlakuan ekstrak daun kayu manis (g/kg) } \\
\cline { 2 - 6 } & 0 & 0,5 & 1 & 2 & 4 \\
\hline Daging (otot) & & & & \\
Kadar air & $78,75 \pm 0,28 \mathrm{bc}$ & $79,51 \pm 0,38 \mathrm{ab}$ & $79,34 \pm 0,37 \mathrm{ab}$ & $78,42 \pm 0,63 \mathrm{c}$ & $79,87 \pm 0,26 \mathrm{a}$ \\
Lemak & $6,65 \pm 0,07 \mathrm{a}$ & $5,31 \pm 0,29 \mathrm{~b}$ & $4,73 \pm 0,32 \mathrm{c}$ & $3,79 \pm 0,24 \mathrm{~d}$ & $2,75 \pm 0,32 \mathrm{e}$ \\
Hati & & & & \\
Kadar air & $73,96 \pm 0,17 \mathrm{~b}$ & $74,91 \pm 0,11 \mathrm{a}$ & $73,87 \pm 0,12 \mathrm{~b}$ & $73,89 \pm 0,32 \mathrm{~b}$ & $73,75 \pm 0,40 \mathrm{~b}$ \\
Lemak & $4,43 \pm 0,27 \mathrm{a}$ & $4,50 \pm 0,19 \mathrm{a}$ & $4,24 \pm 0,53 \mathrm{ab}$ & $4,24 \pm 0,39 \mathrm{ab}$ & $3,72 \pm 0,26 \mathrm{~b}$ \\
IHS & $2,62 \pm 0,20 \mathrm{a}$ & $1,94 \pm 0,39 \mathrm{~b}$ & $1,92 \pm 0,14 \mathrm{~b}$ & $1,88 \pm 0,09 \mathrm{~b}$ & $1,88 \pm 0,23 \mathrm{~b}$ \\
\hline
\end{tabular}

Keterangan: huruf yang berbeda pada baris yang sama menunjukkan pengaruh perlakuan yang berbeda nyata $(\mathrm{P}<0,05)$. Nilai yang tertera merupakan nilai rata-rata dan simpangan baku.

Tabel 3. Total kolesterol, trigliserida, dan HDL-kolesterol ikan patin pada berbagai perlakuan dosis ekstrak daun kayu manis

\begin{tabular}{llcccc}
\hline \multirow{2}{*}{ Parameter uji } & \multicolumn{5}{c}{ Perlakuan ekstrak daun kayu manis $(\mathrm{g} / \mathrm{kg})$} \\
\cline { 2 - 6 } & \multicolumn{1}{c}{0} & 0,5 & 1 & 2 & 4 \\
\hline Kolesterol (mg/dL) & $185,8 \pm 20,4 \mathrm{ab}$ & $182,3 \pm 42,7 \mathrm{ab}$ & $118,9 \pm 48,3 \mathrm{~b}$ & $199,1 \pm 87,2 \mathrm{ab}$ & $226,8 \pm 32,5 \mathrm{a}$ \\
Trigliserida (mg/dL) & $563,2 \pm 7,5 \mathrm{a}$ & $539,2 \pm 29,7 \mathrm{a}$ & $250,5 \pm 148,6 \mathrm{~b}$ & $397,1 \pm 241,8 \mathrm{ab}$ & $482,5 \pm 61,3 \mathrm{ab}$ \\
HDL (mg/dL) & $162,4 \pm 47,2 \mathrm{a}$ & $96,4 \pm 15,9 \mathrm{a}$ & $83,2 \pm 13,1 \mathrm{a}$ & $147,5 \pm 74,3 \mathrm{a}$ & $140,1 \pm 69,7 \mathrm{a}$ \\
\hline
\end{tabular}

Keterangan: huruf yang berbeda pada baris yang sama menunjukkan pengaruh perlakuan yang berbeda nyata $(\mathrm{P}<0,05)$. Nilai yang tertera merupakan nilai rata-rata dan simpangan baku. 
daun kayu manis lebih efektif dimanfaatkan oleh ikan dalam bentuk ekstrak dibandingkan dalam bentuk tepung daun kayu manis.

Penelitian Rolin et al. (2015) menguji pemakaian ekstrak kayu manis dengan dosis yang sama yaitu $0 ; 0,5 ; 1 ; 2 ;$ dan $4 \mathrm{~g} / \mathrm{kg}$ pakan ikan patin. Pada penelitian tersebut didapatkan bahwa dosis 4 $\mathrm{g} / \mathrm{kg}$ menghasilkan laju pertumbuhan harian lebih rendah, sementara ketiga perlakuan lainnya $(0,5$; 1 ; dan $2 \mathrm{~g} / \mathrm{kg}$ ) tidak berbeda nyata dengan kontrol $(0 \mathrm{~g} / \mathrm{kg})$. Kadar lemak berupa kolesterol dan trigliserida terendah pada penelitian ini terdapat pada dosis $1 \mathrm{~g} / \mathrm{kg}$. Berdasarkan hal tersebut dapat dikatakan bahwa perlakuan terbaik dalam penelitian ini adalah penambahan ekstrak kayu manis dengan dosis $1 \mathrm{~g} / \mathrm{kg}$ pakan, karena mampu menurunkan kadar lemak tanpa menurunkan performa pertumbuhan ikan patin.

Rendahnya kadar lemak daging (otot) ini disebabkan lemak digunakan sebagai sumber energi sehingga kadarnya di dalam daging (otot) berkurang. Kebutuhan energi untuk maintenance tercukupi dari karbohidrat dan lemak yang terdapat di dalam pakan, sehingga energi dari protein dapat digunakan untuk pertumbuhan (protein sparring effect). Ekstrak daun kayu manis mengandung senyawa methylhydroxychalcone polymer (MHCP) yang memiliki fungsi seperti insulin (Solomon \& Blannin, 2007; Akilen et al., 2012). Menurut Polakof et al. (2010) insulin sangat berperan dalam proses metabolisme lipid pada hati dan otot (daging). Efek utama insulin pada jaringan adiposa adalah meningkatkan sintesis lipoprotein lipase (LpL) di dalam adiposit. LpL merupakan enzim yang mengkonversi triasilgliserol/trigliserida lipoprotein menjadi gliserol dan FFA.

Kadar lemak hati ikan patin juga cenderung semakin menurun seiring dengan meningkatnya dosis ekstrak daun kayu manis pada pakan (Tabel 3). Hal ini diduga karena komponen bioaktif yang memiliki aktivitas seperti insulin (insulin mimetic) yang terdapat di dalam ekstrak daun kayu manis juga bekerja efektif di hati/hepar. Indeks hepatosomatik ikan yang diberi perlakuan dosis ekstrak $(0,5-4 \mathrm{~g} / \mathrm{kg}$ pakan) lebih rendah dibandingkan kontrol $(\mathrm{P}<0,05)$. Pengukuran indeks hepatosomatik (IHS) bertujuan untuk melihat besarnya penimbunan lemak dan glikogen pada hati. Hati merupakan pusat metabolisme nutrisi di dalam tubuh, dan IHS umum digunakan sebagai indikator pertumbuhan pada ikan. IHS yang rendah menunjukkan penimbunan lemak di hati yang rendah (Craig et al., 2006) karena lemak sebagian besar digunakan sebagai sumber energi.

Kadar total kolesterol dan trigliserida plasma darah ikan patin menurun hingga penambahan ekstrak daun kayu manis sebanyak $1 \mathrm{~g} / \mathrm{kg}$ pakan namun kembali meningkat pada penambahan ekstrak daun kayu manis sebanyak $2 \mathrm{~g} / \mathrm{kg}$ pakan (Tabel 4). Sementara untuk kadar HDLkolesterol sama antarperlakuan akibat dari penambahan ekstrak daun kayu manis ke dalam pakan $(\mathrm{P}>0,05)$. Rendahnya kadar trigliserida ini diduga karena adanya zat MHCP yang terdapat di dalam ekstrak daun kayu manis. Zat MHCP ini akan mengaktivasi peroxisome proliferatoractivated receptors (PPAR) baik PPAR $\alpha$ dan PPAR $\gamma$ (Sheng et al., 2008). Aktivasi PPAR $\alpha$ akan meningkatkan oksidasi asam lemak, sintesis LpL, dan penurunan ekspresi Apo C-III yang merupakan inhibitor LpL sehingga terjadi peningkatan clearance lipoprotein yang kaya trigliserida di dalam plasma darah.

Mekanisme penurunan kolesterol diduga juga karena senyawa polifenol berupa MHCP yang terdapat di dalam ekstrak daun kayu manis bekerja secara efektif. Ekstrak daun kayu manis yang dapat mengaktivasi PPAR $\alpha$ dan PPAR $\gamma$ dapat menurunkan kandungan lipid di dalam plasma darah, menurunkan kadar glukosa darah, serta dapat meningkatkan resistensi terhadap insulin, selain itu ekstrak daun kayu manis juga dapat meningkatkan fungsi hati pada tikus obesitas (Sheng et al., 2008). Hasil penelitian Hlebowicz et al. (2007) dan Blevins et al. (2007) menunjukkan bahwa kayu manis dapat menurunkan level glukosa dan memperlambat laju pengosongan lambung pada penderita diabetes tipe II.

\section{KESIMPULAN}

Penambahan ekstrak daun kayu manis sebanyak $1 \mathrm{~g} / \mathrm{kg}$ pakan memberikan hasil yang optimal karena dapat serta menurunkan kandungan lemak daging, kolesterol, dan trigliserida dibandingkan dengan perlakuan tanpa penambahan ekstrak daun kayu manis (kontrol).

\section{DAFTAR PUSTAKA}

[AOAC] Association of Oficial Analytical Chemists. 2012. Official Methods of Analysis, $19^{\text {th }}$ ed. Airlington: AOAC.

Akilen R, Tsiami A, Devendra D, Robinson N. 2012. Cinnamon in glycaemic control: 
systematic review and meta analysis. Clinical Nutrition 31: 609-615.

Azima F. 2004. Aktivitas antioksidan dan anti-agregasi platelet ekstrak Cassia vera Cinnamomum burmannii Nees ex Blume serta potensinya dalam pencegahan aterosklerosis pada kelinci [Disertasi]. Bogor: Institut Pertanian Bogor.

Blevins SM, Leyva MJ, Brown J, Wright J, Scofield RH, Aston CE. 2007. Effect of cinnamon on glucose and lipid levels in noninsulin-dependent type 2 diabetes. Diabetes care 30: 2.236-2.237.

Chao H, Graves DJ, Anderson R. 2010. Cinnamon extract regulates glucose transporter and insulin-signaling gene expression in mouse adipocytes. Phytomedicine 17: 1.027-1.032.

Hamidah S, Burhanudin V, Istikowati WT. 2009. Kajian sifat-sifat dasar kayu manis sebagai pertimbangan pemanfaatan limbah pemanenan kulit kayu manis Cinnamomum burmanii Blume. Jurnal Hutan Tropis Borneo 10: 210-223.

Hlebowicz J, Darwiche G, Bjorgell O, Almer LO. 2007. Effect of cinnamon on postprandial blood glucose, gastric emptying, and satiety in healthy subjects. The American Journal of Clinical Nutrition 85: 1.552-1.556.

NRC [National Research Council]. 2011. Nutrient Requirements of Fish and Shrimp. Washington DC: The National Academi Press.

Orban E, Nevigato T, Di Lena G, Masci M, Casini I, Gambelli L, Caproni R. 2008. New trends in the seafood market. Sutchi catfish Pangasius hypopthalmus fillets from Vietnam: nutritional quality and safety aspects. Food Chemistry 110: 383-389.

Polakof S, Médale F, Skiba-Cassy S, Corraze G, Panserat S. 2010. Molecular regulation of lipid metabolism in liver and muscle of rainbow trout subjected to acute and chronic insulin treatments. Domestic animal endocrinology 39: 26-33.

Prasad KN, Yang B, Dong X, Jiang G, Zhang H, Xie H, Jiang Y. 2009. Flavonoid contents and antioxidant activities from Cinnamomum spesies. Innovative Food Science and Emerging Technologies 10: 627-632.

Preuss HG, Echard B, Polansky MM, Anderson R. 2006. Whole cinnamon and aqueous extracts ameliorate sucrose-induced blood pressure elevations in spontaneously hypertensive rats. Journal of the American College of Nutrition 25: $144-150$.
Rattanachaikunsopon P, Phumkhachorn P. 2010. Potential of cinnamon Cinnamomum verum oil to control Streptococcus iniae infection in tilapia Oreochromis niloticus. Aquaculture 76: 287-293.

Rolin F, Setiawati, Jusadi D. 2015. Evaluasi pemberian ekstrak daun kayu manis Cinnamon burmannii pada pakan terhadap kinerja pertumbuhan ikan patin Pangasionodon hypopthalmus Sauvage, 1878. Jurnal Iktiologi Indonesia 15: 201-208.

Setiawati M, Jusadi D, Marlinda S, Syafruddin D. 2014. Pemberian daun kayu manis Cinnamomum burmanii dalam pakan terhadap kinerja pertumbuhan dan komposisi nutrien tubuh ikan patin Pangasius hypopthalmus. Jurnal Ilmu Pertanian Indonesia 19: 80-84.

Setiawati M, Sakinah A, Jusadi D. 2015. Evaluasi pertumbuhan dan kualitas daging Pangasianodon hypopthalmus yang diberi pakan mengandung daun Cinnamomum burmanni. Jurnal Akuakultur Indonesia 14: 171-178.

Sheng X, Zhang Y, Gong Z, Huang C, Zang YQ. 2008. Improved insulin resistance and lipid metabolism by cinnamon extract through activation of peroxisome proliferationactivated receptors. PPAR Research 2008: 1-9.

Solomon TPJ, Blannin AK. 2007. Effects of shortterm cinnamon ingestion on in vivo glucose tolerance. Diabetes, Obesity, and Metabolism 9: 895-901.

Sulistiyani, Sufriadi A, Safithri M. 2006. Manfaat daun kayu manis Cinnamomum burmannii terhadap khasiat antioksidasi mahkota dewa Phaleria macrocarpa Scheff Boerl selama penyimpanan. Seminar Kelompok Kerja Nasional Tanaman Obat Indonesia (POKJANAS TOI). Solo, 24-25 Maret 2006

Suryaningrum TD, Muljanah I, Tahapari E. 2010. Profil sensori dan nilai gizi beberapa jenis ikan patin dan hibrid nasutus. Jurnal Pascapanen dan Bioteknologi Kelautan dan Perikanan 5: 153-164.

Suwarsito. 2007. Pengaruh L-karnitin terhadap kadar lemak daging dan komposisi tubuh ikan patin Pangasius hypopthalmus. Journal of Fisheries Sciences 9: 63-68.

Vanschoonbeek K, Thomassen BJ, Senden JM, Wodzig WK, van Loon LJ. 2006. Cinnamon supplementation does not improve glycemic control in postmenopausal type 2 diabetes patients. The Journal of Nutrition 136: $977-$ 
980.

Wang R, Wang R, Yang B. 2009. Extraction of essential oils from five cinnamon leaves and identification of their volatile compound compositions. Innovative Food Science and
Emerging Technologies 10: 289-292.

Watanabe T. 1988. Fish Nutrition and Mariculture. Tokyo University of Fisheries: Department of Aquatic Bioscience. 